Article

\title{
Exploring Strategy-Making in 'Non-New Public Management' Public Services Settings: The Case of European Union Agencies
}

\author{
Edoardo Ongaro ${ }^{1, *}$ and Ewan Ferlie ${ }^{2}$ (D) \\ 1 School of Business, Open University, Walton Hall, Milton Keynes MK76AA, UK \\ 2 King's Business School, King's College, London WC3B 4WH, UK; ewan.ferlie@kcl.ac.uk \\ * Correspondence: edoardo.ongaro@open.ac.uk
}

Received: 14 January 2019; Accepted: 26 February 2019; Published: 11 March 2019

check for updates

\begin{abstract}
A growing public management literature has debated whether strategic management models originally developed for private firms are also relevant to contemporary public agencies. Thus far, it has been easier to apply strategic management models centred on competitive advantage in jurisdictions in which new public management (NPM) reforms have left an enduring inheritance, with the emphasis in these settings on the autonomization of public agencies and a prominent concern with 'performance'. Based on the case study of public agencies in the European Union, we argue there is potential to apply strategic management models in other jurisdictions where the penetration of NPM has been much lower, provided certain conditions of agency autonomy are met and factors-such as stakeholders' expectations stimulating the adoption of strategic management models-perform as the functional equivalent of the pressures provided by NPM incentivization systems. The paper contributes to the literature aimed at employing the discipline of strategic management - a thriving field of inquiry business administration and management—as a valuable source of knowledge for the advancement of public management.
\end{abstract}

Keywords: public management; public strategic management; European Union; public agencies; research policy; educational and vocational training policy

\section{Introduction}

This paper considers the issue of whether the discipline of strategic management-a thriving field of inquiry in the broader discipline of business administration and management that has so far been underutilized in public administration-can provide valuable knowledge for the advancement of public management, specifically, whether strategic management models can be usefully applied to improve the understanding of decision-making processes in contemporary public agencies; and if so, whether and how contextual differences across national jurisdictions may affect the adoption of strategic management approaches.

A growing public management literature has debated whether strategic management models originally developed for private firms are also relevant to contemporary public agencies (Andrews et al. 2006; Berry 1994; Boyne and Walker 2004; Bryson et al. 2010; Meier et al. 2007; Nutt and Backoff 1993). It has so far been easier to apply strategic management models centred on competitive advantage to settings based on new public management (NPM), e.g., the United Kingdom (UK), and to some extent the United States (US), with their emphasis on the autonomization of public agencies, their concern with 'performance' (Andrews et al. 2006) and widespread adoption of market-type mechanisms within public services (Ferlie et al. 1996; Porter and Teisberg 2006). Reforms of the public sector inspired by such doctrines also led to the development of performance management systems within public 
services organizations, creating conditions more akin to commercial sector firms competing in markets. However, NPM-based jurisdictions represent a relatively limited number of countries: indeed most countries across Europe, Asia, Africa or Latin America have only partially, if at all, adopted NPM reforms, and further, NPM reforms may not have had deep transformative effects over the ways in which the public sector works in some countries which superficially appear as NPM orientated. We call these non-NPM institutional settings, and in this paper we distinctively explore whether some models of strategic management can be fruitfully applied to such non-NPM settings. So, our main (theoretical) research question is whether strategic management models find applicability also in low-NPM settings, and if so under what conditions this may happen. Secondly, our related empirical research question is what models of strategic management can be detected in these settings.

We should point out that the generic strategic management literature has since long broadened its scope beyond conventional industrial economics and the historically influential Porterian school centred on market competitive advantage (Porter 1980, 2008). Other schools seek to develop nonmarket approaches to strategic management, which potentially have higher significance for application to public services settings. Examples of alternative approaches are: the strategy-as-practice movement, the resource-based view, the learning school, and the cultural school (see Mintzberg et al. 2009). So our contribution is to explore the question of whether some models of strategic management can be usefully applied to public agencies in 'low NPM' settings, rather than the more studied 'high NPM' settings where applications can already be found (Bryson et al. 2010; Ferlie et al. 1996). We argue there is potential to apply strategic management models to low NPM settings, provided certain conditions of agency autonomy are present, and, secondly and complementary to this argument, that factors such as stakeholders' expectations-acting through various non market based mechanisms-may stimulate the adoption of strategic management models, acting as the functional equivalent of the pressures provided by NPM incentivization systems.

We start by reviewing relevant strategic management literatures. After outlining our methods, we present and discuss two case studies of strategic processes in public agencies in the European Union (EU), selected as a low-NPM setting. We conclude that certain strategic management models (namely, the collective design school; strategy as practice) are empirically evident. We then draw out theoretical implications about the strategy process of public services organizations in low-NPM public management settings. Ultimately, we aim to contribute to the accumulation of knowledge about how to systematically employ strategic management models for bettering the understanding of the behavior of public organizations in a range of public settings internationally.

\section{Literature Review: The Proliferation of Strategic Management Models and Intersectoral Transfer}

Several newer models of strategic management (Pettigrew et al. 2006; Ferlie and Ongaro 2015) are evident in the wider literature; some of these approaches to strategic management have already crossed into public management scholarship.

The initial and somewhat narrow focus of the public management literature was on the importing of formal strategic planning in the 1980s. Berry (1994) saw its adoption as fuelled by new Reaganite politics that encouraged American public agencies to manage better within limited resources and curtail their old social activism; Llewellyn and Tappin (2003) explored strategic planning in national park agencies in the USA and the UK and suggested such plans helped public managers acquire resources from governmental sponsors and also rhetorically signalled a more managerial stance ('getting results'). Strategic plans were no longer 'dormant documents' and could act to challenge traditional professional dominance.

Bryson's latest version of his influential text on strategic planning (Bryson 2018) proposes a model of a broad 'strategy change cycle'. It incorporates processes such as organizational learning, leadership, organizational change and iterative reflection. This model recasts strategic planning as a wider form of practical reasoning, getting beyond seeing it as a purely rational-analytic or technical activity. 
Bryson et al. (2010) literature review notes the recent proliferation of generic strategic management models, alongside and beyond strategic planning. Perspectives like organizational learning and knowledge management as well as the literature on the 'practice turn' (Johnson et al. 2007; Fenton and Langley 2011) are considered; the latter is a powerful new prism which conceives of 'strategy' as a collective, micro level, activity, best seen in day-to-day action where organizational actors 'strategize'.

Bryson and other public management scholars sympathetic to strategic management thinking have also suggested that generic models may require (substantial) adaptation to public agency settings. Vining (2011) considers whether Porter's well known 'five forces' framework (Porter 1979)—originally developed for private firms-applies to public agencies. He concludes some forces can be readily transposed, but other dimensions are more problematic: stronger political influence remains a key modifier for public agencies.

Finally, some 'old schools', like the design school (Mintzberg et al. 2009), have enjoyed wide applicability in public services settings. The design school seeks to achieve a strategic fit between a particular organization and its environment (not necessarily defined as a market) (Ferlie and Ongaro 2015, p. 13; Mintzberg et al. 2009). Here, strategy is normally led by the Chief Executive Officer (CEO) and advisers, then handed to middle management to implement. The school suggests that 'strategic vision' should be simple, be bespoke to each organization (rather than following general principles) and easy to communicate to others. It uses well-known techniques (such as SWOT and PESTEL) to analyze the environment and organizational strengths and weaknesses (Mintzberg et al. 2009). Bryson (2018) contains extensive examples of SWOT in American public agencies.

Importantly, there has also been a strand of literature developing approaches to strategic management in public organisations which originated firmly within the field of public management. This strand is often based on the authors' heavy involvement in concrete experiences of processes of strategic renewal of public organisations, providing original syntheses of models of strategic management within public services organisations (Lega and Cristofoli 2009; Joyce 1999; Joyce and Drumaux 2014).

So there are now various strategic management models applicable to public agencies, which do not assume a firm operating in competitive markets, and which can potentially provide a repertoire of conceptual models to interpret the behavior of public organisations through the lens of strategic management in non-NPM institutional settings. However, we have noted from the earlier literature review that most applications of strategic management have occurred in 'high-NPM' settings, paving the way for the question explored here of whether and how strategic management based approaches find applicability outside the relatively narrow set of countries where NPM reforms have left a heavy mark.

\section{Applying Models of Strategic Management to Non-NPM Public Agencies}

The 'fit' of a strategic management model may also depend on the administrative-organizational form of public agencies within a national jurisdiction. NPM-based reforms (Hood 1991) in the UK and other jurisdictions created new public agency forms. Rosenberg and Rosenberg and Ferlie (2014) define three characteristics of NPM-orientated public agencies as follows: (i) they are endowed with some significant autonomy to operate; (ii) they face incentivization, notably performance related budgets; and (iii) they are marketized, facing market led competition. It might be easier to apply some strategic management models in these 'firm-like' settings. They then explore strategy-making in such settings by using resource-based view concepts and market like Porterian prisms within NPM-style UK and Danish public agencies. For example, many English hospitals are now Foundation Trusts of the National Health Service (NHS): while they are still publicly funded bodies rather than firms with shareholders, they have more operational freedoms, including a lifting of the cap on money from private patients. Greve (2006, p. 165) argues Denmark is heavily influenced by NPM, with public management reforms that contract out, deregulate, stimulate consumer choice and promote efficiency. 
Rosenberg (2011) suggests NPM reforms to Danish schools have led to increased use of strategic management tools such as SWOT, mission statements and customer analyses there.

So NPM reforms facilitate the adopting of generic strategic management models in public agencies. Yet comparativists (Christensen and Laegreid 2013; Painter and Peters 2010; Pollitt and Bouckaert 2011) have noticed different national trajectories of public management reform, and certainly there is no global convergence on the NPM paradigm. The potentially transformative effects of NPM reforms (Hood 1995; Christensen and Laegreid 2013) are differentially received. The question is whether 'high impact' NPM reforms are a precondition for adoption of strategic management approaches in public agencies. To address this fundamental question, we pose the following research questions here research questions: (i) empirically, is strategic behavior evident in non-NPM public services settings, and if so, (ii) how should this strategic behavior be analyzed theoretically?

These questions raise issues of defining the core features of a low NPM public agency. We suggest they are the opposite of the conditions discussed above for a high NPM agency, namely that they are: (i) located in traditional and non-autonomized organizational forms; (ii) based on nonperformance related funding; and (iii) do not face market conditions.

Secondly, we need to select 'low' NPM jurisdictions and study public agencies within them. Painter and Peters (2010) characterize different administrative traditions, including the Anglo-American (often 'high NPM'), and the Napoleonic (e.g., France) and the Germanic traditions, both lower NPM (Barzelay and Fuechtner 2003; Ongaro 2009). Pollitt and Bouckaert (2011) distinguish between NPM-based jurisdictions (e.g., UK; New Zealand) and Continental European states, seen as Neo Weberian (or 'Weber lite') jurisdictions, including the European Union (EU) (Ongaro 2015). Pollitt and Bouckaert (2011, pp. 257-58) see the EU administration as only open to NPM and private management based ideas within certain limits.

A notable trend there has been the development of EU 'public agencies': there were just two in the early 1990s but over forty by 2010. EU agencies are defined as governmental entities that possess and exercise some grant of specialized public authority, but are neither directly elected by the people, nor directly managed by elected officials (Thatcher and Sweet 2002, p. 2). Some political science literature has considered the determinants for establishing such agencies. Distributional conflict and the influence of the EU supranational organizations (chiefly the Commission), rather than functional imperatives, appear to drive this process. Political compromises amongst multiple 'principals' (Dehousse 2008), encompassing both EU Member States and the European Commission, help explain their establishment (Kelemen and Tarrant 2011).

EU agencies are not the product of dis-aggregation, driven by a specialization logic and the search for higher performance: they are in these respects altogether different from NPM style executive agencies (Pollitt et al. 2004). Quite the opposite, EU level agencies execute new public functions previously wielded in a separate manner by the Member States: they are new entities for executing novel tasks, not a new organizational form for performance-enhancement purposes. There is no incentivization system built-in other than 'Weberian' statutory obligations for task execution and due process. They also have a monopoly in their remit, with neither markets nor quasi-markets forming the resource environment where they operate.

EU agencies thus display core traits which contrast strongly with NPM style executive agencies (Ongaro et al. 2012), namely: (i) they are not established within a novel and allegedly more efficient organizational form, but rather as new bodies for executing a public function within a traditional organizational form; (ii) they do not have built-in incentivization systems; (iii) they are not 'marketized', or operating in markets or quasi-markets. Finally, while they enjoy some autonomy, they do not reflect a process of 'autonomization', or the purposeful endowing of higher autonomy to 'let managers manage', within a performance-enhancing system. 


\section{Research Design and Methods}

This section discusses our research design and operational methods. The design is a longitudinal and comparative case study of two EU agencies: the European Training Foundation (ETF-it may be noted the appellation of 'foundation' in the official name of ETF may be misleading, as this is an agency of the EU in all respects, and not a foundation in any legal meaning of the word) and the European Research Council Executive Agency (ERCEA). We used this approach because our research questions are exploratory and 'how' questions (is a strategic behavior evident in non-NPM settings? How can such strategic behavior be studied theoretically?), for which this design is appropriate. The empirical fieldwork followed an initial literature review to help us design the interview pro forma, reflecting a theoretically informed rather than a grounded theoretical/purely inductive approach.

\subsection{Case Selection}

Candidate agencies were initially identified from the population of EU agencies. They needed to have been operating long enough for a strategy process potentially to have unfolded at the time of the empirical investigation (2011-13). We selected two cases which varied across various significant dimensions, including:

- $\quad$ Age: whether the agency is relatively 'old' (established before 2000) or 'young' (established in the 2000s); ETF was a pioneer (established in 1994); ERCEA more recent (established 2007, operational 2009); agency age is significant as patterns of consistent decisions may take time to form.

- Duration: whether the agency has by statute an indefinite duration (ETF), or is temporary (ERCEA has a 'termination date' linked to its research program, although legally the mandate can be renewed if the program is). Such variation may affect the strategy process, if 'survival' is an implicit but overarching agency goal.

- Size: (staff and budget size): EU agencies are often 'small' organizations in staff terms, but a distinction can be made between those below or just about 100 staff (small, like ETF), and those with 300 or above (large, like ERCEA); in terms of approximate budget ETF is 20 million euro/year, yet ERCEA 2000 million euro/year.

- $\quad$ Type of task: tasks typically executed by EU agencies include: Information gathering; advice; scrutiny and inspection; authorization/adjudication; disbursement of grants/subsidies; and service delivery. ETF evolved from service delivery to policy advice tasks; while ERCEA disburses scientific grants.

- Corporate governance: the most diffuse governance model is a board with representatives from all EU member states-one each—plus the Commission; as in ETF; the main alternative is a board composed of sector 'experts', as for ERCEA.

- Management of scientists/epistemic communities: certain agencies rely on advice from expert professionals, such as epistemic communities of scientists (e.g., ERCEA); others do not (ETF).

\subsection{Data Collection Procedures}

Our approach to data collection is based on the criterion of the triangulation of sources. So we sought multiple sources for ascertaining the events that form the case study narratives on which the subsequent analysis is founded. A first source consisted of documentary data-data that were accessed include: the formal act establishing the agency; other regulatory acts; multi-year plans; minutes of board meetings; reports and other agency 'factsheets'; documentation of meetings; EU and sectoral documentation on agency activities.

A second source was face-to-face interviews with selected key informants: generally, the director general/executive director; all other agency senior executives, in both line and staff functions, forming the top management team; governing board members (usually the chairman or deputy chairman); and 
other stakeholders. These were very senior people so the interviews were most informative. Thirteen in-depth formal interviews were undertaken.

Many informal talks with these and other informants also took place. Some became 'intimates', with whom it was possible to exchange views and ask for additional information informally.

After the literature review and pilot empirics, a final interview protocol for semi-structured interviews was crafted. It covered: the history of the agency; history of (prima facie) strategy-making events; and explored the formation of strategy according to different possible schools (using Mintzberg et al. 2009 as a reference).

All questions were open-ended. 'A priori identified' interview questions were supplemented with questions considered fruitful to pursue during the interview (Eisenhardt 1989, p. 547). Indeed, many questions-most empirical, at times interpretive-emerged in interviews. Interviews were long and lasted between one and three hours and a half. When more time was needed, respondents always agreed. Whilst permission to tape record the interview was always asked, only some were tape-recorded: initial interviews showed that respondents were more at ease without tape recording. Transcripts of notes from all interviews were produced and cross-checked with respondents.

The final interviews (chronologically speaking) provided only corroborating evidence to prior accounts (they pointed to the same 'facts' as 'landmarks' and the same actors playing a key role), suggesting empirical saturation was reached.

In the ETF case, an additional source of data collection was attendance (direct observation) at two conference-based initiatives where one author observed the way ETF managed relationships with its key stakeholders.

Further data originated from direct observations during multiple site visits to the agencies. Field notes were taken (providing ongoing commentary based on both observation and analysis). Ethical approval from the sponsoring University was received.

\subsection{Data Analysis: The Narrative Approach to Process Analysis}

The unit of analysis is the strategy-making process in the two agencies. Methodologically, one can identify alternative approaches for theorizing from process data. Langley (1999) reviews different models: the one employed here is the narrative approach based on constructing a detailed story from raw data. Classic examples of this genre within strategic management include: Chandler (1962) and, for public sector settings, Barzelay and Campbell (2003). Narratives serve different purposes, which suggest different treatments of data. First, they may be 'a preliminary step aimed at preparing a chronology for subsequent analysis-essentially, a data organization device that can also serve as a validation tool' (Langley 1999, p. 695). These descriptive (as opposed to explanatory) narratives answer questions about 'what has occurred'. Such early steps may lead to higher order analytical narratives aiming to 'clarify sequences across levels of analysis, suggest causal linkages between levels, and establish early analytical themes' (Pettigrew 1990, p. 280). The goal is to explore and explain case histories, but then move to attempts to generalize analytically beyond the extant cases (Pettigrew 1990, p. 280).

We will now present analytic narratives of both cases, followed by cross-case comparison to develop more analytical themes and, ultimately, address our second, theory building, research question.

\subsection{The Two Case Studies-Introduction}

The story of the European Training Foundation (ETF) tracks how a mainly service-delivery organization attained a policy advisory role-which can be seen as a higher-status task-within the EU polity. The agency found a niche where it could thrive, and acquired the resources (mainly skilled staff) to reposition itself. Such repositioning occurred over the period from the early 2000s to the early 2010s and was driven by a response to menacing circumstances (the termination of the agency was alluded to in the early 2000s). The unfolding of events shows the importance of collective leadership 
and of the appropriation of specific events as key practices whereby the new role and status of the organization is built and legitimized.

The storyline of the European Research Council Executive Agency is of a new-born agency becoming over a few years (2007-14) the single most important research grant agency in the EU, shaping the criteria whereby very substantial resources are allocated (nearly two billion euros per year). A cohesive epistemic community, strong collective leadership, and certain strategic practices explain the unfolding of the story.

\section{The European Training Foundation: A Strategic Turn from Project Management to a Policy Advisory Agency}

The ETF was formally established in 1990 and became operational in 1994. Until the early 2000s, it was mainly engaged with delivering technical assistance services in education and vocational training in third country recipients of EU-funded programs. Its core competence was one of project management. Then, a major strategic turn occurred, and between 2000 and 2010 agency tasks and its very position in the EU institutional-administrative environment changed. ETF became a provider of high-level policy advice to these third country recipients and a major actor of vocational education and training policies there. Staff have since been operating as policy advisors to governments in Asia, the Caucasus, the Near East, the Mediterranean area and the Balkans.

How did it happen that this public agency changed its mandate, the core tasks, the skills and competencies available to execute them, its key relationships and interdependencies with EU institutions (chiefly the Commission), and more broadly its 'position' in the EU administrative system? How did such a process, which we see as a 'strategic turn', unfold? We argue that a set of actors-variously entering and exiting decision opportunities and interacting in various and differentiated ways over time-jointly operated shrewdly to steer the re-orientation of the agency. They managed to achieve legitimacy from key external stakeholders for such a turn. This process occurred in an environment fraught with threats for the very survival of the agency. We argue that taking a strategic management perspective allows us more thoroughly to interpret the observed 'repositioning'. Specifically, we argue the design school combined with the strategy-as-practice approach provides an apt theoretical framework to analyse how this strategic turn occurred.

Soon after ETF started (1994), developments in the EU-funded programs aimed at supporting the transition of former Soviet bloc countries to democratic institutions and free market economy provided the frame in which ETF found its well-recognised original function, namely delivering technical assistance in vocational training (chiefly monitoring the execution of EU-funded programs).

Then the circumstances changed dramatically. After the resignation of the European Commission executive led by Jacques Santer (in the year 1999) due to a financial scandal, reform of the governance and management of the Commission gained prominence and led to various interventions in financial and personnel management (Ongaro 2012, 2013). Under new regulations, the Commission was forbidden to outsource tasks in external relations, including the technical assistance ETF was providing. So, some in the Commission (and elsewhere) raised the issue of "what to do with ETF? Kill it?". Moreover, some countries originally recipients of EU technical assistance were on their way to completing EU accession, hence becoming members of the board of the agency and no longer clients of it. The new financial regulation also reduced the need for a monitoring agency. The situation had suddenly become fluid and had at stake the role and the very survival of the agency.

However, the transforming environment was bringing not just threats, but potential opportunities as well: whilst former accession countries were exiting the remit of ETF, the nascent European Neighbourhood Policy would make new countries enter the scope of EU external policy. At the same time, the European public discourse known as the 'Lisbon agenda for the competitiveness of Europe' outlined a program of reforms marked by concepts such as 'lifelong learning' and 'lifetime education', which opened up a new policy space for the agency. 


\subsection{Multiple Actors Enter the Decision Opportunities}

How was ETF to cope with the transforming environment? A decisive intervention came from Mrs. Catherine Day, a high official representing the Commission in the governing board of ETF, later to become the Secretary General of the Commission. The move that turned out to be a watershed event occurred when she sent a letter-specifically, an email—to various officials within the Commission, which circulated widely and in which she outlined a 'vision' for ETF. The main thesis was that ETF should become a source of expertise and support to Commission Delegations (EU 'embassies' in third countries) and that its task should be to shape the education policy of the recipient countries, so that they were 'aligned' with EU goals. Project management tasks would be outsourced for the most part to the recipient countries' governments.

Actors in different DGs of the European Commission reacted differently; but a decisive intervention came from within the agency. An external evaluation had been commissioned to a consultancy; the central evaluative question was the future tasks and mandate of ETF: 'what does ETF have to do?'. The final report was delivered, and officially discussed at the Governing Board meeting in late 2002. The at the time director Peter De Rooij and his aides exploited the opportunity to comment on the evaluation report before its final adoption to stress the passage about the opportuneness to cast a new mandate for ETF. A breach was introduced which triggered the process that eventually led to the recasting of the mandate: the recommendation was made for ETF to adopt 'a new clear statement of the overall mission'. Soon after, the Director of ETF of the time intervened in front of the Education Committee of the European Parliament, one of the two EU legislative bodies. The other legislative body, the Council of Ministers, which is formed by the governments of the EU Member States, was also targeted by the ETF director. This process eventually led to the recasting of the founding regulations and the new competencies that were incorporated in the mandate of the agency.

\subsection{The 'Torino Process': Stakeholder Fora Seen as a Strategic Practice}

Such a 'proactive' stance from the ETF director, however, was not his initial one: he earlier resisted the prospect of abandoning the 'project monitoring' tasks and the threatened downsizing of ETF that could go with it. A meeting that marked the collective perception about the need to change and gave shape to a shared sense of direction was the Advisory Forum held in November 2003, with partner countries, member states, and the Commission. The subject of the meeting was 'learning matters' and suggested ETF could showcase-and was on that occasion recognised to have the legitimacy to provide - three kinds of knowledge: of vocational training and education policies, of the recipient countries (where ETF had been operating over a decade), and of the administrative functioning of EU programs. The forum was conceived by a close aide of De Rooij, Peter Grootings, who first envisaged the prospects associated with embracing a new role for ETF. After this event, ETF started to have a conscious perspective, a kind of shared vision, about what it was to become.

A second forum was held three years later, in 2006: the 2006 forum demonstrated the importance of consulting and of networking in EU neighbouring countries where ETF was active. The third forum held in 2009 formalised the so-called 'Torino' process (ETF is located in Turin, or Torino in the Italian language). In sum, the 2003 forum performed a catalytic function for the initial strategic turn, whilst successive events and the triggering of the Torino process performed the complementary function of developing and consolidating the new 'vision' of ETF as a provider of policy advice.

\subsection{Building Capabilities}

The unfolding of the strategic change that occurred at ETF requires the recounting of another event when a major program called TEMPUS was taken back from ETF to the Commission and reassigned to another agency. This event occurred in 2005-06 when another director, after the expiry of the second mandate of De Rooij, was in post. The new director, Muriel Dunbar, had general managerial 
competences but no specific knowledge of the field of vocational training. She addressed the issue of what to do with the staff that used to work at the program:

"The bargain was: 'you keep the budget, we move away the programme, you take care of the people'. And we did it, in a number of ways: by having people move internally, to fill ETF vacancies; or by providing career guidance support to find another job (in the Commission, or in the executive agency that took care of TEMPUS); eventually, only two people remained. Only later we could fill ten to twelve new posts to hire staff with the new skills required)."1

The process was painful (and resulted in some judicial appeals) and absorbed most of the energies of the ETF director serving in the role that time. However, eventually, ETF managed to ensure that most posts could be kept on the organisation chart, and they then firmly proceeded to replace the existing staff with new staff possessing different skills required for the policy advisory role, such as education economics.

\subsection{Interpreting Strategic Change through the Frame of the 'Design School' and the 'Strategy-as-Practice' Approach}

What form did strategy take in this case? In some respects it was explicit: formalised in documents exchanged with the Commission and other EU institutions and approved by the governing board and in legally binding EU acts. It may also be interpreted as deliberate: from the letter sent out by Mrs Day and addressed to the decision makers involved in recasting the mandate of ETF, to the public hearings made by the pro tempore ETF director in front of the competent parliamentary committee. A clear vision for ETF was championed by certain key actors from the early phases of the strategic change process. In other words, strategy in the case appears to be both formalized and deliberate (Mintzberg et al. 2009).

Content-wise, the novel and threatening circumstances that took shape around 2000 were mostly regarded as provoking a misfit between the changing environment (interpreted as a set of external threats and opportunities) and the internal configuration of ETF (seen as no longer adequate to the environment), for which a bespoke solution was sought. The subsequent changes to the statute and hence mandate of ETF are a reflection and embodiment of the strategic turn that occurred, hence in a sense 'policy change' was driven by strategic change, rather than the other way around.

Put together, these elements-strategy as a deliberate attempt to lead the organisation by certain key actors, strategy as searching for a proper fit between the organisation and the environment, strategy as 'bespoke' and unique to the organisation-fit well with the design school of strategic management, aptly summarised by Mintzberg et al. (2009, chp. 2).

However, the original design school often assumes one individual (typically the CEO) to be the pivotal actor and the architect of the strategy. In this public agency setting, the initial framework has to be amended to accommodate the presence of a collective actor-some individuals composing it even being institutionally affiliated to other organisations-as 'the strategist'. Importantly, in fact, the story points to the joint action of actors who entered (and exited) the decision opportunities at different points in time as having steered the agency's re-orientation. Jointly, they imagined, built up capacity, and legitimated a 'new vision' for the agency as an EU centre of expertise in education and vocational training. In other words, these actors acted collectively to design the new strategy, even if each brought only a subset of the 'components' necessary for effecting the new vision. Indeed, they did not have full agreement amongst themselves, nor did they necessarily behave in consistent and unambiguous ways over time (March 1999; Talbot 2005); but the courses of action they undertook jointly imagined, legitimated and built up the capacity needed for the new vision to become reality. Specifically, Catherine Day provided the original vision for ETF, and strongly legitimated it, at least within the Commission, as the parent administration with important oversight powers over ETF. 
Peter de Rooij and Peter Grootings picked up such a vision, elaborated it, and communicated it both internally, towards ETF staff, and externally, towards the European Parliament and Member States, thus legitimating it. De Rooij's successor, Mrs. Muriel Dunbar, set up the organizational process of acquisition of new skills to build up the capabilities needed for the new role. The ETF director since 2009, Madlen Serban, further developed and completed the process of building up these capacities, aptly exploiting the 'Torino process', both symbolically and practically, for getting full recognition and legitimacy by stakeholders. The theoretical underpinnings for the interpretation of 'practices' as embodying or making the strategy (rather than just being a manifestation of it) are indeed provided by the strategy-as-practice approach (Jarzabkowski and Wilson 2002; Jarzabkowski et al. 2007; Jarzabkowski and Spee 2009) briefly reviewed earlier.

Summing up, the design school when combined with the strategy-as-practice approach provide a theoretically based interpretation of how strategy unfolded at ETF (strategy as 'fit' between internal configuration and external configuration, strategy as deliberate, strategy as unique, strategy as made through key events and practices).

\section{The Power of Ideas: Strategy-Making at the European Research Council Executive Agency}

The program 'IDEAS' took shape in the 7th planning period, starting in the year 2007, of the so-called 'Framework Programme' (FP7) through which the EU administers its research policy (the third largest item in the Community budget). At the core of the IDEAS funding scheme was the simple notion that 'the big ideas that have made the history of mankind have first been in one mind': the funding of research — the reasoning followed—should help ideas with a high potential of engendering novel discoveries to move to the experimental stage. The success factor for this policy is the ability to identify 'high potential' ideas stemming from all possible thematic areas without any a priori restriction of the topics to be funded.

The European Research Council (ERC) was set up by the European Commission as the institutional framework to implement the IDEAS program. It is a research funding body with the goal of fostering 'cutting edge' research in Europe. It consists of a Scientific Council and an Executive Agency. Set up in 2007, the Scientific Council was composed of eminent scientists across various disciplines. It was intended to 'represent' the whole European scientific community and ensure the needs of the scientific community are expressed and translated into the criteria whereby the grants are allocated. An executive agency, named ERCEA (European Research Council Executive Agency), which was set up in 2007 and has been operational since 2009, performs operational tasks in supporting the functioning of the funding scheme.

IDEAS represented a truly novel programme and soon displayed impressive growth, administering three thousand research projects over a time span of less than six years. The ERC reached a budget of 1.8 billion euro per year in 2013, following a steep increase in its initial assigned budget. The ERC became, in a remarkably short time span, an authoritative voice in European research policy.

What led to such a 'success' story? Was it just the shrewd initial design of the public program which determined its success, or have other factors weighed in? What is meant by 'strategy' in the case of an organisation pervasively steered by its parent administration like an EU executive agency, and whose duration is linked to the length of the program it is mandated to implement (the termination clause)? And where is the locus of such 'strategy' in a governance architecture that includes an independent Scientific Council—formed exclusively of scientists—as not just the guarantor of the highest scientific standards but also as the 'game-maker' in program delivery? As we shall see, the design school of strategic management explains an important part of this second case study story, provided such a framework is properly qualified.

\subsection{Scientists and Administrators Coalesce in Leading Strategically the ERC}

The establishment of the IDEAS programme required the appointment of the members of the ERC Scientific Council. The first round of appointments was carried out in 2005 by a 'high level' 
panel of independent experts set up by the European Commission. The ERC started operations in 2007, at the time administratively supported by four units of the Directorate General 'Research and Technological Development' (DG RTD) of the Commission (before the agency ERCEA was established). Whilst some members were already acquainted with the EU machinery of research programmes, as project managers of EU-funded research projects, all the prominent scholars were chosen for scientific achievements, bringing with them 'a vision which was totally scientific', hence often uninterested in the mechanics of EU research policy. The scientific Council had the final word in defining the criteria whereby the ERC funding schemes would operate: it was 'entrusted the entire envelope' (to use a practitioner's expression), that is, the significant amount of financial resources with which IDEAS would operate. A key task lay in identifying experts for the panels in charge of assessing the proposals and awarding grants, while also setting the criteria according to which such panels should operate.

Some initial decisions taken by the Scientific Council had a significant impact. The first key issue concerned funding criteria. The decision was rapidly made to proceed only along a bottom-up approach: themes of research were not pre-identified by the ERC, but proposals could be formulated by scientists on any topic, with no restrictions on the allocation of funds to subject areas: it was the number of approved research project proposals which drove the allocation of money to the subject areas. In the words of a member of the Scientific Council, 'the power was given to scientists', meaning both the evaluators of the panels and the broader scientific community from which research project proposals originate. This approach was at the opposite pole, as an organizing criterion, from the rest of the EU Framework Programme (FP7): the thrust was to distinguish the IDEAS programme from the other EU Framework Programmes.

The second key issue concerned how to organize what was labelled 'first class' peer review, to ensure funds would be allocated only to top quality proposals. It was decided to set up panels through the direct initiative of ERC members: it was the ERC Scientific Council that proposed and appointed lists of scholars as panel members. Alternatives such as setting up a call for reviewers or other options were discarded: the Scientific Council took all the responsibility for naming the names approached in forming the panels.

A third influential decision was the portability of grants: it was decided that, should a grant holder move to another institution, the grant (or what remains unspent) is transferred to the new host institution, thus making grant-holders attractive for universities and other research institutions willing to become poles for frontier research.

The executive agency was established by Commission Decision in December 2007 to implement the IDEAS programme. It became administratively operational in July 2009. The director was chosen amongst European Commission officials through an internal procedure. The agency was tasked to support the work of the Scientific Council and the panels in selecting the research project proposals received, administer the grants, and ensure compliance with IDEAS regulation. The executive agency was organised in three departments: the Scientific Management Department (in charge of supporting the evaluation process leading to the assignment of grants), the Grant Management Department (in charge of the administration of the grant 'after it has been assigned' and through the whole life cycle), and the Resources and Support Department (providing support services).

The first director of the agency was Jack Metthey, a senior European Commission official with extensive experience in research policy and management. The immediate challenge he faced was endowing the agency with enough staff to process the rapidly growing number of applications: in the first call of the IDEAS program about 9000 applications were received, whilst expectations were for between 2000 and 3000. The challenge was to expand the panels and find panelists: the Scientific Council (producing lists of experts) and the Scientific Support Department (arranging their 'enrolment') managed to work together effectively to set up 20 panels (across the three main domains: Social Sciences and Humanities; Life Sciences; Physical and Engineering Sciences), that in 2008 became 25, operating through about 1500 panel members. This development occurred over just a couple of years. A practice adopted was to set at fifteen the maximum number of members for each panel (to facilitate internal 
coordination and cohesion among members); combined with the ceiling of 25 panels and coupled with the practice of further 'splitting' funding lines when required to cope with increased application numbers, this became a managerial "formula" (fifteen by twenty-five) whereby the Scientific Council coped with increasing volumes.

\subsection{Guiding Ideas as Ideational Bases of Organizing}

The way the ERC framed the provision of research funding was shaped by two strong yet simple ideas. First, the idea that, ultimately, 'it is scientists to know where to go' to move knowledge further: it followed that, to promote research at the frontier of human knowledge, a bottom-up approach —without a priori prescriptions about what fields of inquiry 'should' be privileged-was adopted. Organisational complexities could now be narrowed down to setting up administrative machinery whose only guiding criterion was the thorough assessment of the inherent quality of the research proposal.

The other guiding idea was 'big ideas first come in one mind', in the mind of one person only (it was Isaac Newton who discovered and formulated the law of universal gravity, or Albert Einstein who elaborated the theory of relativity): here was a clear idea from which it followed that the kind of research to be considered for ERC funding should be research projects whose concept and design come from one individual scientist: it is the (potentially) big idea that one individual wants to pursue that should be funded, and not large-scale projects-however ambitious they may be-that develop further already established streams of scientific inquiry. This means that projects should be both innovative and relatively simple, since one person only is to be in charge of it. The grant then allows the scientist to set up a research team, which s/he leads as the principal investigator, but the overall project should be small enough so that one individual may keep control of it. This meant the appraisal process should perform the two functions of detecting the innovativeness of the project, probing its feasibility, and assessing the quality of the applicant via their track-record. But there was no need to assess large-scale project proposals against long lists of formal program priorities, as occurred in other domains of European research funding. Potentially high organisational complexity was narrowed down through a powerful filter about what kind of proposals the agency would process: that is, restrained in size and highly innovative.

When analysed from their administrative implications, such guiding ideas (right or wrong as they may be from the substantive epistemological viewpoint of whether such is the way in which human knowledge progresses) filtered away the organisational complexity of arranging the evaluation of large-scale proposals. At the same time, the sharing amongst the staff of such ideas helped permeate the organisation with a strong sense of mission: staff conceived of themselves as contributing to moving forward the frontiers of knowledge.

\subsection{Collective Leadership and Organizational Design}

Over a few years, the ERC became a major actor in its own right in the research policy landscape. The succession in the post of President of the Scientific Council in 2010 (when Professor Helga Nowotny replaced Professor Fotis Kafatos) and of the director of the executive agency (Mr. Pablo Amor, a senior Commission official who was previously head of the Scientific Management Department, took office as agency director in early 2011) did not alter the overall direction: a constellation of actors (both internal and external) operated in a consistent way to ensure the steady growth of the ERC in terms of its administered resources and its international standing. They pursued a stable course of action marked by the choice to adopt a totally a bottom-up approach, whereby themes of research could be formulated by scientists on any topic without restrictions. By taking the responsibility to appoint all panel members upon the direct initiative of the ERC members (who suggested the scholars for the assessment panels), as well as assuming a decisive role in defining criteria to be followed in assessing proposals, they provided a clear direction to the novel and forming organisation and substantiated its thrust towards asserting itself as a pivotal player in European research, and one that was there to 
stay-even though its legal foundation conferred only a temporary status upon it (the agency continues to exist if and only if the program is renewed for another cycle).

\subsection{Interpreting Strategic Change through the Frame of the 'Design School'}

Strategy in this case was composed of simple and straightforward decisions, clearly formulated and communicated before being (rapidly) implemented, that together provided strong sense of direction and perspective about where the ERC was heading. Certain guiding ideas provided the bases of organizing: the bottom-up approach (the avoidance of any pre-defined thematic area), the focus on small-scale, highly innovative projects, the 'formula' of the ceilings to the number of disciplinary panels (set to 25 with the members of each panel set to fifteen). This way, the internal configuration of the agency furnished and developed the capabilities required for ensuring consistent selection of grant-winners and support to principal investigators across Europe, providing the 'fit' with the external expectations it faced stemming from both the scientific community and EU decision-makers.

This search for agency/environment 'fit' suggests a picture consistent with the design school of thought (see Mintzberg et al. 2009, pp. 23-49). However, rather than a 'solo player', or the CEO being apparent as the chief strategist (Porter 2008), a set of actors again operated collectively as the strategist. This set created a coalition, or at least a coalescing of actors operating in a cohesive way, across epistemic and organisational borders (such as scientists and European Commission civil servants working side by side, in the scientific council and the executive agency).

\section{Concluding Discussion and Our Contribution}

\subsection{Empirical Contribution: Models of Strategic Management in Use}

Which models of strategy were empirically evident in use? Both cases support the explanatory power of the Design School, provided it is adapted to include a collective, composite strategist. In the ETF case, actors entered and exited decision opportunities at different points; yet their collective action provided for the agency's strategic management. Indeed, they did not necessarily have full internal agreement, but their actions jointly imagined, legitimated and built up capacity for the new vision to be developed and implemented. Such collective action, too, produced a coalescing of actors in the ERCEA case, where the glue of a common belonging to an epistemic community facilitated group cohesion.

In the ETF case, strategy-making additionally unfolded around key events (the stakeholders' conferences which were dubbed as the 'Torino process') as 'strategic practices' that created conditions for, and embodied, the strategic turn. This finding supports the Strategy-as-Practice perspective, advocating the micro-level study of concrete strategizing practices (Johnson et al. 2007; Jarzabkowski and Spee 2009). Such a perspective suggests the importance of strategic behavior in board meetings, away days or a business or strategic planning exercise (e.g., SWOT), or in stakeholder conferences. There is here a focus on understanding micro-level human agency as opposed to more macro level and Porterian market structure. It also assumes a wider cast of actors than solely the CEO. This perspective may fit well with public and non for profit settings as it does not assume strong markets and because it is open to strategy-making from below, including from powerful professions often present in various public services settings (see Gioia and Chittipeddi 1991; Oakes et al. 1998; Jarzabkowski and Wilson 2002; Denis et al. 2010): such as the scientists in the ERCEA case. The design and the strategy-as-practice schools may therefore complement each other in explaining the forming and unfolding of strategy in such agencies.

Summing up, our empirical finding is that strategy can form in such 'low NPM' settings, as EU agencies. NPM transformative reforms are not necessary preconditions for strategic behavior to be apparent in public services organizations. The two EU cases suggest the (collective) design school and strategy as practice schools of thought in strategic management are evident empirically, as both do not require market forces to be in operation. 


\subsection{Theoretical Contribution: Explaining Strategic Processes in Low-NPM Public Agencies}

Why, theoretically, can agencies in low-NPM settings display some internal strategic capacity and so form their own strategy? We argue that, firstly, some conditions of agency autonomy are present which enable the forming of strategy in the public contexts beyond the narrow case of NPM-driven autonomization, and that, secondly and complementary to this argument, factors such as the pressure wielded by the expectations of powerful stakeholders, acting through various non market based mechanisms, may stimulate the adoption of strategic management models, These pressures act in this regard as the functional equivalent of the pressures provided by NPM incentivization systems (which are often market or quasi-market based).

Starting from the dimension of autonomy, which can be seen as both a condition and a goal of strategic action in public agencies settings (Vining 2011), autonomy may be granted to-or won by-public services organizations for reasons beyond conventional NPM rationales. Public agencies which have been set up on bases other than performance-enhancement may still enjoy significant autonomy, thus enabling space for local strategy formation, which in turn may reinforce the extent of autonomy enjoyed. In EU agencies, conditions of autonomy, firstly, originated from statutory prescriptions of technical-scientific independence as well as delegated formal autonomy to recruit staff. Beyond such legal requirements, we here refer to some social science-based research which has been carried out on the topic of the autonomy of public agencies. In a seminal work, Verhoest et al. (2004) go beyond legal prescriptions to consider the behavioral elements enacted in such settings: 'thus the autonomy of a public agency refers to the level of independence vis-à-vis the government in actually using the delegated decision-making competences' (p. 105). Verhoest et al. (2004) consider financial autonomy (the extent to which agency's executives may decide on financial resources without external approval), personnel management autonomy (executives' control over human resources-staffing, recruitment, reward and promotion/demotion, dismissal) and policy autonomy (in relation to policy tools or objectives) as key autonomy dimensions of a public agency. Based on this framework, Verhoest and colleagues' carried out an extensive investigation into the autonomy of public agencies across European countries-mostly jurisdictions that can be squarely placed in the 'Low-NPM' category. Their research empirically shows that public agencies in continental Europe may enjoy relatively high levels of autonomy (Verhoest et al. 2012). Extensive NPM-ization is not therefore a prerequisite for public agencies to be endowed with significant autonomy.

More specifically, another piece of empirical inquiry shows that EU agencies also enjoy a relatively high level of autonomy at least in some respects: a survey-based investigation of the level of autonomy of EU agencies carried out in accordance with Verhoest and colleagues' framework indicates that EU agencies display relatively low financial autonomy, but relatively high personnel management autonomy and also high policy autonomy (Ongaro et al. 2015), a finding which has been replicated for the two agencies investigated in the later and more qualitative research work now reported in this article.

Alongside agency autonomy, a second complementary set of factors also explains the strategic capacity displayed by public agencies in low-NPM settings which was detected in our empirical study of ETF and ERCEA. This second set of factors consists of stakeholders' expectations, which can provide further pressures toward the adoption of strategic management models by the agency. Stakeholders' expectations in low NPM settings perform as the functional equivalent of the built-in incentivization systems that are often found in high NPM settings and that have been deemed there to be conducive to the adoption of strategic management models.

In sum, the argument we put forward is that a driver of strategy formation in public agencies in low-NPM settings comes from their key and more powerful stakeholders' expectations. Such expectations may enable would-be strategists of the kind seen in the case studies presented here to adopt strategic management models. So stakeholders' expectations might perform in low NPM settings a function similar to the one performed by built-in incentivization systems (like market-type mechanisms) present in high NPM settings. 
To illustrate, the ambitious expectations from key milieus in the European scientific community towards what ERCEA could contribute to European science, and the expectations by senior EU decision-makers within the Commission about ETF contribution to education policy-under the threat of termination-supplied a rationale for these two agencies to adopt a strategy. The specific content of the strategy varied (expansionist in the ERCEA case, repositioning in a niche for ETF), yet in both cases strategy was highly influential in shaping the future of the public agency.

To further elaborate on this point, we can then question through what (non-market) mechanisms do such expectations from powerful stakeholders act on public agencies? Firstly, the ETF case suggests that the credible threat at the senior policy-maker level of losing agency jurisdiction (up to the point of threat of agency termination) may act as an important analogue within low NPM settings of the pressures exercised by the top down performance management systems found in high NPM settings (so that the attribution of threat to the situation can be seen as an activated social mechanism (McAdam et al. 2001, pp. 43, 95). In addition, the case illustrates senior policy-makers can also provide important support which facilitates the agency's strategic turn.

The case also highlights the role of high internal 'absorptive capacity' (Cohen and Levinthal 1990), enabling a public agency to sense, absorb and then act on information about threats. ETF's high 'absorptive capacity' enabled it to respond to credible threats it perceived it its environment and undertake a complex and rapid transformation and 'upscaling' of its mandate, enabling it to get out of menacing circumstances that could have led to a very different and much more ominous outcome.

The ERCEA case also suggests a third mechanism: the operation of a process of jurisdictional building through the successful and legitimate cooptation of scientists and their epistemic field, through meeting their collective demands and expectations. We find parallels in (Selznick [2009] 2015)'s classic study of the Tennessee Valley Authority (TVA) in America which explored how it too sought to generate support and build autonomy and strategic direction. The TVA was an experimental agency in the New Deal of the 1930s, of which it became a symbol. Selznick's interpretation (Selznick [2009] 2015, p. 67) stressed TVA's 'cooptation' of established local interest groups (e.g., land grant colleges) to build a constituency and survive in a conservative region. The ERCEA case suggests a similar pattern with the cooptation of the European scientific community.

Ideological elements also help shape what are seen as legitimate and somewhat protected modes of decision-making. The TVA was notable for its strong collective ideology of 'grass roots planning', a claim with quasi democratic and morally suffused undertones difficult to contest. In ERCEA, the governing council and the scientific community held strong shared beliefs that proper decision-making was bottom-up (coming from the science) rather than top down: this ideological slant led the agency to proceed through peer review letting scientists drive resource allocation. These beliefs-also difficult to contest-institutionalized bottom-up scientific control over the resource allocation process and strongly limited the scope for top down interventions.

Summing up, a combination of conditions of agency autonomy and, second and complementary, factors acting - through a range of social mechanisms-as driving forces of strategic behavior can explain the actual adoption of strategic management models in low NPM settings. So our two cases empirically suggest that strategic behavior by public agencies is possible in low NPM settings, such as the EU, just as it is in the more studied experience of executive agencies in the high-NPM setting of the UK.

Finally, we suggest the study of strategic management in public agencies is still developing and so far concentrated in high NPM sites. More research work to explore how strategic management unfolds in non-NPM-based agencies may provide the grounding for, firstly and empirically, detecting what models of strategic management are employed in a greater variety of systems, and, secondly and more theoretically, achieving a deeper understanding of what can explain these patterns of agency autonomy and decision-making.

Author Contributions: The work is a joint product of the authors; however, E.O. is first author and in the final version wrote Sections 3-6, while E.F. wrote Sections 1 and 2. 
Funding: This research received no external funding.

Conflicts of Interest: The authors declare no conflict of interest.

List of Interviews and Codification

\begin{tabular}{cccc}
\hline Agency & Place $^{2}$ & Position & Codification \\
\hline ERCEA (European Research Council Executive Agency) & Brussels & Executive & ERCEA Interview 1 \\
ERCEA (European Research Council Executive Agency) & Brussels & Executive & ERCEA Interview 2 \\
ERCEA (European Research Council Executive Agency) & Brussels & Executive & ERCEA Interview 3 \\
ERCEA (European Research Council Executive Agency) & Brussels & Executive & ERCEA Interview 4 \\
ERCEA (European Research Council Executive Agency) & Brussels & Executive & ERCEA Interview 5 \\
ERCEA (European Research Council Executive Agency) & Brussels & Executive & ERCEA interview 6 \\
ETF (European Training Foundation) & Turin & Executive & ETF Interview 1 \\
ETF (European Training Foundation) & Turin & Executive & ETF Interview 2 \\
ETF (European Training Foundation) & Turin & Executive & ETF Interview 3 \\
ETF (European Training Foundation) & Turin & Executive & ETF Interview 4 \\
ETF (European Training Foundation) & Turin & Executive & ETF Interview 5 \\
ETF (European Training Foundation) & Turin & Executive & ETF Interview 6 \\
ETF (European Training Foundation) & Turin & Executive & ETF Interview 7 \\
\hline
\end{tabular}

\section{References}

Andrews, Rhys, George A. Boyne, and Richard M. Walker. 2006. Strategy content and organizational performance: An empirical analysis. Public Administration Review 66: 52-63. [CrossRef]

Barzelay, Michael, and Colin Campbell. 2003. Preparing for the Future: Strategic Management in Government. Washington: The Brookings Institutions.

Barzelay, Michael, and Natascha Fuechtner. 2003. Explaining Public Management Policy Change: Germany in Comparative Perspective. Journal of Comparative Policy Analysis 5: 7-27. [CrossRef]

Berry, Frances Stokes. 1994. Innovation in public management: The adoption of strategic planning. Public Administration Review 54: 322-30. [CrossRef]

Boyne, George A., and Richard M. Walker. 2004. Strategy content and public service organizations. Journal of Public Administration Research and Theory 14: 231-52. [CrossRef]

Bryson, John. 2018. Strategic Planning for Public and Non Profit Organizations, 5th ed. San Francisco: Jossey Bass. Bryson, John M., Frances S. Berry, and Kaifeng Yang. 2010. The state of public strategic management research: A selective literature review and set of future directions. The American Review of Public Administration 40: 495-521. [CrossRef]

Chandler, Alfred D. 1962. Strategy and Structure. Chapters in the History of American Enterprise. Cambridge: MIT Press.

Christensen, Tom, and Per Laegreid, eds. 2013. The Ashgate Research Companion to the New Public Management. Farnham: Ashgate.

Cohen, Wesley M., and Daniel A. Levinthal. 1990. Absorptive capacity: A new perspective on learning and innovation. Administrative Science Quarterly 35: 128-52. [CrossRef]

Dehousse, Renoud. 2008. Delegation of Powers in the European Union: The Need for a Multi-principals Model. West European Politics 31: 789-805. [CrossRef]

Denis, Jean-Louis, Ann Langley, and Linda Rouleau. 2010. The practice of leadership in the messy world of organizations. Leadership 6: 67-88. [CrossRef]

Eisenhardt, Kathleen M. 1989. Making fast strategic decisions in high-velocity environments. Academy of Management Journal 32: 543-76.

Fenton, Christopher, and Ann Langley. 2011. Strategy as practice and the narrative turn. Organization Studies 32: 1171-96. [CrossRef]

2 Date not disclosed for ensuring anonymity. 
Ferlie, Ewan, and Edoardo Ongaro. 2015. Strategic Management in Public Services Organisations: Concepts, Schools, and Contemporary Issues. Abingdon: Routledge Taylor Francis.

Ferlie, Ewan, Lynn Ashburner, Louise Fitzgerald, and Andrew Pettigrew. 1996. The New Public Management in Action. Oxford: Oxford University Press.

Gioia, Dennis A., and Kumar Chittipeddi. 1991. Sensemaking and sensegiving in strategic change initiation. Strategic Management Journal 12: 433-48. [CrossRef]

Greve, Carsten. 2006. Public management reform in Denmark. Public Management Review 8: 161-69. [CrossRef]

Hood, Christopher. 1991. A public management for all seasons? Public Administration 69: 3-19. [CrossRef]

Hood, Christopher. 1995. The "New Public Management" in the 1980s: Variations on a theme. Accounting, Organizations and Society 20: 93-109. [CrossRef]

Jarzabkowski, Paula, and Andreas Paul Spee. 2009. Strategy as Practice: A review and future directions for the field. International Journal of Management Reviews 11: 69-95. [CrossRef]

Jarzabkowski, Paula, and David C. Wilson. 2002. Top teams and strategy in a UK university. Journal of Management Studies 39: 355-81. [CrossRef]

Jarzabkowski, Paula, Julia Balogun, and David Seidl. 2007. Strategizing: The Challenges of a Practice Perspective. Human Relations 60: 5-27. [CrossRef]

Johnson, Gerry, Ann Langley, Leif Melin, and Richard Whittington. 2007. Strategy as Practice: Research Direction and Resources. Cambridge: Cambridge University Press.

Joyce, Paul. 1999. Strategic Management for the Public Services. Buckingham and Philadelphia: Open University Press.

Joyce, Paul, and Anne Drumaux. 2014. Strategic Management in Public Organizations: European Practices and Perspectives. New York: Routledge.

Kelemen, R. Daniel, and Andrew D. Tarrant. 2011. The political foundations of the eurocracy. West European Politics 34: 922-47. [CrossRef]

Langley, Ann. 1999. Strategies for Theorizing from Process Data. Academy of Management Review 24: 691-710. [CrossRef]

Lega, Federico, and Daniela Cristofoli. 2009. Strategic Public Management. Milan: EGEA.

Llewellyn, Sue, and Emma Tappin. 2003. Strategy in the public sector: Management in the wilderness. Journal of Management Studies 40: 955-82. [CrossRef]

March, James G. 1999. Understanding How Decisions Happen in Organisations. In The Pursuit of Organisational Intelligence. Malden and Oxford: Blackwell, pp. 13-38.

McAdam, Doug, Sidney Tarrow, and Charles Tilly. 2001. Dynamics of Contention. Cambridge: Cambridge University Press.

Meier, Kenneth J., Laurence J. O’Toole, George A. Boyne Jr., and Richard M. Walker. 2007. Strategic management and the performance of public organizations: Testing venerable ideas against recent theories. Journal of Public Administration Research and Theory 17: 357-77. [CrossRef]

Mintzberg, Henry, Bruce Ahlstrand, and Joseph Lampel. 2009. Strategy Safari: Your Complete Guide through the Wilds of Strategic Management, 2nd ed. Harlow: FT Prentice Hall.

Nutt, Paul C., and Robert W. Backoff. 1993. Organizational publicness and its implications for strategic management. Journal of Public Administration Research and Theory 3: 209-31.

Oakes, Leslie S., Barbara Townley, and David J. Cooper. 1998. Business planning as pedagogy: Language and control in a changing institutional field. Administrative Science Quarterly 43: 257-92. [CrossRef]

Ongaro, Edoardo. 2009. Public Management Reform and Modernization: Trajectories of Administrative Change in Italy, France, Greece, Portugal and Spain. Cheltenham: Edward Elgar.

Ongaro, Edoardo. 2012. Editorial Introduction: Managerial reforms and the transformation of the administration of the European Commission. International Review of Administrative Sciences 78: 379-82. [CrossRef]

Ongaro, Edoardo. 2013. The administrative reform trajectory of the European Commission in comparative perspective: Historical New Institutionalism in compound systems. Public Policy and Administration 28: 346-63. [CrossRef]

Ongaro, Edoardo. 2015. Administrative reforms in the European Commission and the Neo-Weberian model. In The Palgrave Handbook of the European Administrative System. Edited by Michael Bauer and Jarle Trondal. Basingstoke: Palgrave, pp. 108-23. 
Ongaro, Edoardo, Dario Barbieri, Paolo Fedele, and Davide Galli. 2012. EU Agencies. In Government Agencies. Practices and Lessons from 30 Countries. Edited by Koen Verhoest, Sandra Van Thiel, Per Laegreid and Geert Bouckaert. Basingstoke: Palgrave MacMillan, pp. 400-12.

Ongaro, Edoardo, Dario Barbieri, Nicola Bellé, and Paolo Fedele. 2015. EU Agencies and the European Multi-Level Administrative System. In Multi-Level Governance: The Missing Linkages. Edited by Edoardo Ongaro. Bingley: Emerald, pp. 87-124.

Painter, Martin, and B. Guy Peters. 2010. Administrative traditions in comparative perspective: Families, groups and hybrids. In Tradition and Public Administration. London: Palgrave Macmillan, pp. 19-30.

Pettigrew, Andrew M. 1990. Longitudinal field research on change: Theory and Practice. Organization Science 1: 267-92. [CrossRef]

Pettigrew, Andrew M., Howard Thomas, and Richard Whittington, eds. 2006. Handbook of Strategy and Management. London: Sage.

Pollitt, Christopher, and Geert Bouckaert. 2011. Public Management Reform: A Comparative Analysis. Oxford: Oxford University Press.

Pollitt, Christopher, Colin Talbot, Janice Caulfield, and Amanda Smullen, eds. 2004. Agencies: How Governments do Things through Semi-Autonomous Organizations. Basingstoke: Palgrave.

Porter, Michael E. 1979. How Competitive Forces Shape Strategy. Harvard Business Review 57: 137-45.

Porter, Michael E. 1980. Competitive Strategy. New York: Free Press.

Porter, Michael E. 2008. Competitive Advantage: Creating and Sustaining Superior Performance. New York: Simon and Schuster.

Porter, Michael E., and Elizabeth Olmsted Teisberg. 2006. Redefining Health Care: Creating Value-Based Competition on Results. Cambridge: Harvard Business Press.

Rosenberg, Hansen Jesper. 2011. Application of Strategic Management Tools after an NPM-Inspired Reform Strategy as Practice in Danish Schools. Administration E Society 43: 770-806.

Rosenberg, Hansen Jesper, and Ewan Ferlie. 2014. Applying strategic management theories in public sector organizations: Developing a Typology. Public Management Review 18: 1-19. [CrossRef]

Selznick, Philip. 2015. TVA and the Grassroots: A Study in the Sociology of the Formal Organization. Berkeley: University of California Press. First published 2009.

Talbot, Colin. 2005. The Paradoxical Primate. Exeter and Charlottesville: Academic Imprint.

Thatcher, Mark, and Alex Stone Sweet. 2002. Theory and Practice of Delegation to non-Majoritarian Institutions. West European Politics 25: 1-22. [CrossRef]

Verhoest, Koen, Sandra Van Thiel, Per Laegreid, and Geert Bouckaert, eds. 2012. Government Agencies. Practices and Lessons from 30 Countries. Basingstoke: Palgrave.

Verhoest, Koen, B. Guy Peters, Bouckaert Geert, and Bram Verschuere. 2004. The Study of Organisational Autonomy: A Conceptual Review. New York: John Wiley and Sons.

Vining, Aidan R. 2011. Public agency external analysis using a modified "five forces" framework. International Public Management Journal 14: 63-105. [CrossRef]

(C) 2019 by the authors. Licensee MDPI, Basel, Switzerland. This article is an open access article distributed under the terms and conditions of the Creative Commons Attribution (CC BY) license (http:// creativecommons.org/licenses/by/4.0/). 